\title{
The Barthel index-dyspnea a tool for respiratory rehabilitation: reply to the letter by Chuang [Letter of clarification]
}

This article was published in the following Dove Press journal:

International Journal of COPD

8 March 2017

Number of times this article has been viewed

\author{
Mauro Carone' \\ Michele Vitacca ${ }^{2}$ \\ Mara Paneroni \\ Paola Baiardi ${ }^{3}$ \\ Antonio Spanevello ${ }^{4,5}$ \\ Giorgio Bertolotti ${ }^{6}$ \\ 'Respiratory Division, ICS MAUGERI \\ SPA SB, Institute of Cassano Murge \\ (BA) IRCCS, Italy; ${ }^{2}$ Respiratory \\ Rehabilitation Division, ICS MAUGERI \\ SPA SB, Institute of Lumezzane (BS) \\ IRCCS, Italy; ${ }^{3}$ Scientific Direction, ICS \\ MAUGERI SPA SB, Institute of Pavia, \\ IRCCS, Italy; ${ }^{4}$ Respiratory Rehabilitation \\ Division, ICS MAUGERI SPA SB, \\ Institute of Tradate (VA) IRCCS, Italy; \\ ${ }^{5}$ Respiratory Diseases Unit, University \\ of Insubria, Varese; 'Psychology Unit, \\ ICS MAUGERI SPA SB, Institute of \\ Tradate (VA) IRCCS, Italy
}

\section{Dear editor}

We read the remarkable letter by Chuang. ${ }^{1}$ We thank him for his valid suggestions on our paper. Interestingly, he focused on the two dimensions of the Barthel indexdyspnea (BI-d), which was exactly our goal. As rehabilitators, our goal is to provide patients with physical therapy depending on their health status and to improve their respiratory function.

We need to verify and demonstrate the efficacy and the outcomes of respiratory rehabilitation, supported by physical therapy. For these reasons, we need an assessment device that measures respiratory improvement during daily motor activities that should be monitored.

The modified Barthel index ${ }^{2}$ is a well-consolidated and widely used instrument to assess the performance of a person in a predetermined and fixed set of activities of daily living (ADLs). By proposing BI-d, ${ }^{3}$ we aimed to develop a scale to measure how dyspnea precludes or reduces the same ADLs, with the ultimate goal of globally assessing the effectiveness of rehabilitation. Hence, an assessment method that measures the impact of dyspnea on activities monitored by a rehabilitation program is of utmost importance for rehabilitators.

Large part of Chuang's letter is based on the Chronic Respiratory Questionnairedyspnea (CRQ-d). The CRQ-d is a health-related quality of life (health status) questionnaire, with a dyspnea "domain". ${ }^{4}$ However, for our purposes, the CRQ-d is too individualized as each subject selects five activity items - "the most important" - out of 26 listed activities. Therefore, each subject may choose different items from other subjects in the same study group. Due to this significant methodology, CRQ was standardized recently into a version that contains a total of only five items with a dyspnea domain, all of which have to be responded. ${ }^{5}$

Conversely, the modified Barthel index ${ }^{2}$ includes a predetermined and fixed set of ADLs. This allows better comparison between subjects or group of subjects, before and after a treatment, a significant criterion in rehabilitation, and a specific field for which we mainly developed the scale. Moreover, CRQ-d is dyspnea centered, whereas BI-d is activity centered.

This first paper on BI-d validation is auspicious. The metric qualities are good and the variability is acceptable, with $95 \%$ confidence intervals of correlation coefficient of BI-d versus 6 -minute walking test being -0.609 and -0.352 , respectively.
Via per Mercadante km 2, 70010 Cassano delle Murge (BA), Italy

Email mauro.carone@icsmaugeri.it 
Table I Four clinical cases according to GOLD severity criteria of obstruction: stages I-4

\begin{tabular}{|c|c|c|c|c|c|c|c|c|c|c|}
\hline $\begin{array}{l}\text { Patient } \\
\text { no }\end{array}$ & GOLD & $\begin{array}{l}\text { BMI } \\
\left(\mathrm{kg} / \mathrm{m}^{2}\right)\end{array}$ & $\begin{array}{l}\mathrm{FEV}_{1} \% \\
\text { predicted }\end{array}$ & $\begin{array}{l}\text { FVC } \% \\
\text { predicted }\end{array}$ & TI & Drug & & $\begin{array}{l}\text { Rehabilitation } \\
\text { sessions number }\end{array}$ & $\begin{array}{l}\text { LTOT } \\
\text { TO }\end{array}$ & $\begin{array}{l}\mathrm{PaO}_{2} \\
\mathrm{TO}\end{array}$ \\
\hline$\# I$ & I & 39.7 & 87 & 67 & 65 & LAMA & & 20 & No & 89 \\
\hline$\# 2$ & 2 & 25.1 & 62 & 96 & 65 & LAMA & & 21 & No & 62 \\
\hline$\# 3$ & 3 & 25.7 & 45 & 105 & 43 & LAMA & IICS & 27 & No & 81 \\
\hline$\# 4$ & 4 & 34.0 & 27 & 58 & 46 & LAMA & IICS & 30 & Yes & 77.1 \\
\hline $\begin{array}{l}\text { Patient } \\
\text { no }\end{array}$ & $\begin{array}{l}\mathrm{PaCO}_{2} \\
\text { T0 }\end{array}$ & $\begin{array}{l}\mathrm{pH} \\
\text { TO }\end{array}$ & $\begin{array}{l}\mathrm{PaO}_{2} I \\
\mathrm{FiO}_{2}\end{array}$ & $\begin{array}{l}\text { 6MWT } \\
\text { T0 }\end{array}$ & & $\begin{array}{l}\text { 6MWT } \\
\text { TI }\end{array}$ & $\begin{array}{l}\text { Barthel } \\
\text { T0 }\end{array}$ & $\begin{array}{l}\text { Barthel } \\
\text { TI }\end{array}$ & $\begin{array}{l}\text { BI-d } \\
\text { T0 }\end{array}$ & $\begin{array}{l}\text { Bl-d } \\
\text { TI }\end{array}$ \\
\hline$\# I$ & 47 & 7.41 & 423.81 & 410 & & 435 & 100 & 100 & 6 & 5 \\
\hline$\# 2$ & 41 & 7.47 & 295.23 & 280 & & 345 & 98 & 100 & 22 & 5 \\
\hline \#3 & 42 & 7.47 & $385.7 \mid$ & 245 & & 310 & 100 & 100 & 38 & 20 \\
\hline$\# 4$ & 52.2 & 7.42 & 273.00 & 125 & & 230 & 80 & 90 & 39 & 20 \\
\hline
\end{tabular}

Abbreviations: BMI, body mass index; FEV , forced expiratory volume in I second; FVC, forced vital capacity; TI, Tiffeneau-index (FVC/FEV ); LTOT, long-term oxygen therapy; T0, at baseline; $\mathrm{PaO}_{2}$, partial pressure of oxygen; $\mathrm{PaCO}_{2}$, partial pressure of carbon dioxide; $\mathrm{pH}$, logarithm of the reciprocal of hydrogen ion concentration; FiO inspiratory fraction of oxygen; 6MWT, 6-minute walking test; BI-d, Barthel index-dyspnea; TI, at the end of the rehabilitation program; LAMA, long-acting muscarinic agent; LABA, long-acting $\beta 2$ agonist; ICS, inhaled corticosteroid; GOLD, Global Initiative for chronic Obstructive Lung Disease.

As pointed out in our paper, additional studies in respiratory rehabilitation programs are required to further assess the applicability of the scale in a broadest context. Mild COPD patients are among those populations who are potential candidates of BI-d. Dr Chuang showed accurately that only $8.1 \%$ of our study population had mild COPD. This is obvious as COPD is largely underestimated, and patients usually consult a specialist only when they are diagnosed with GOLD $2^{6}$ stage disease. ${ }^{7-9}$ Table 1 and Figure 1 show a few outcomes of four subjects based on the four GOLD stages. They also show that the less obstructed the patient, the lower the BI-d was. Conversely, the more obstructed
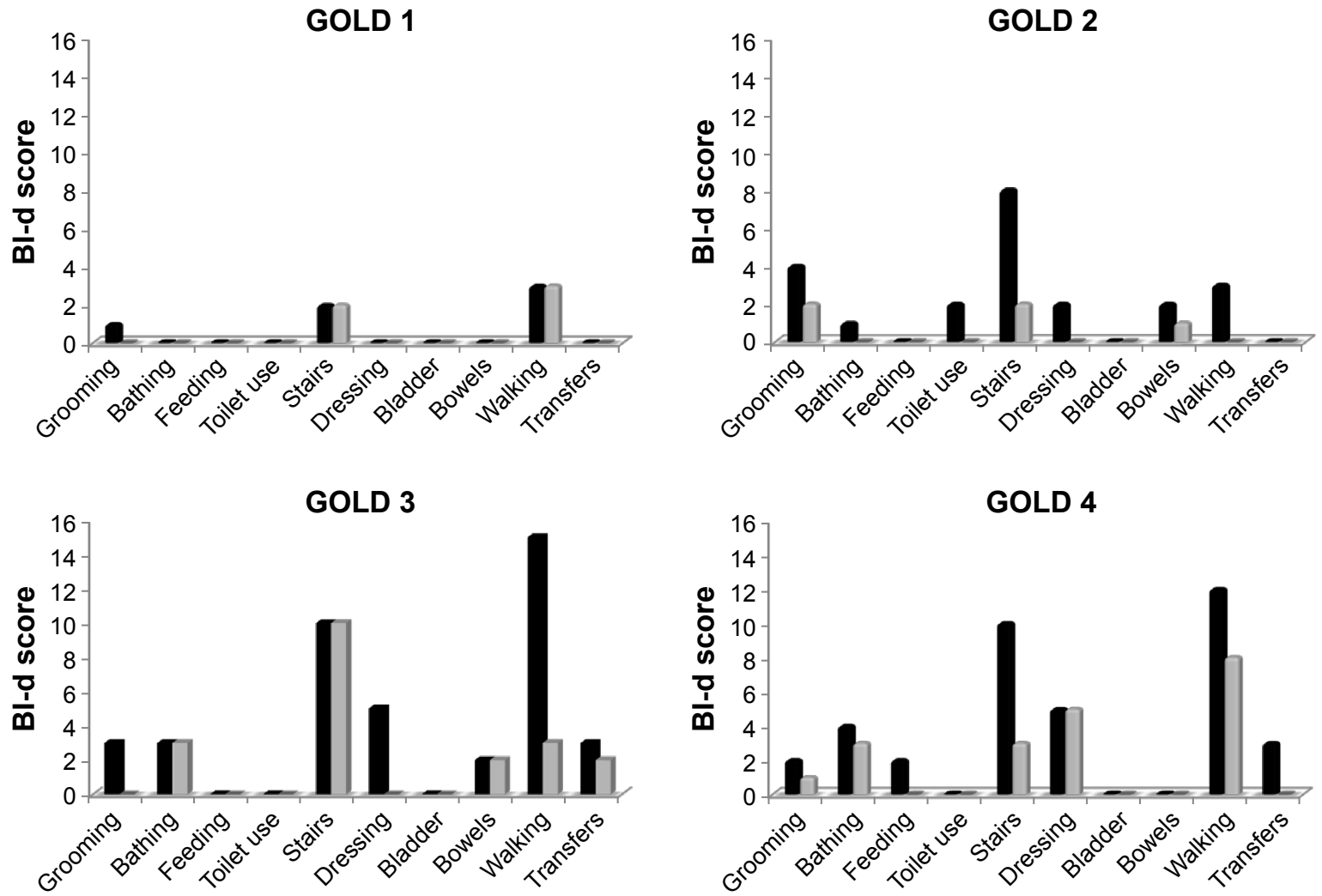

Figure I Mean score distribution of each Barthel dyspnea item measured at the baseline (black columns) and at the end (gray columns) of the rehabilitation program. Subjects were subdivided according to GOLD severity grade.

Abbreviations: BI-d, Barthel index-dyspnea; GOLD, Global Initiative for chronic Obstructive Lung Disease. 
the patient, the higher the BI-d was. After pulmonary rehabilitation, the BI-d improved in all patients. The best results were observed in GOLD 4 stage as they received a more intensive health care and rehabilitation program. On the other hand, the smallest limitation was assessed at the baseline, and the smallest differences in outcome were observed in subjects at GOLD 1 stage.

\section{Conclusion}

In conclusion, we consider it appropriate to uphold all items of both the modified Barthel index score (because they collect important information from a physical rehabilitation point of view) and of the Barthel dyspnea index (because they allow the estimate of the outcome of a specifically tailored respiratory rehabilitation program).

\section{Disclosure}

The authors report no conflicts of interest in this communication.

\section{References}

1. Chuang ML. The Barthel index-dyspnea: a new two-dimensional dyspnea scale. Int J Chron Obstruct Pulmon Dis. 2016;11:1843-1844.
2. Shah S, Vanclay F, Cooper B. Improving the sensitivity of the Barthel index for stroke rehabilitation. J Clin Epidemiol. 1989;42(8):703-709.

3. Vitacca M, Paneroni M, Baiardi P, et al. Development of a Barthel index based on dyspnea for patients with respiratory diseases. Int J Chron Obstruct Pulmon Dis. 2016;11:1199-1206.

4. Lacasse I, Wong E, Guyatt GH. Individualising questionnaires. In: Joyce CRB, O’Boyle CA Mc Gee H, editors. Individual Quality of Life. Amsterdam: Harwood Academic Publishers; 1999:87-104.

5. Schünemann HJ, Griffith L, Jaeschke R, et al. A comparison of the original chronic respiratory questionnaire with a standardized version. Chest. 2003;124(4):1421-1429.

6. Rabe KF, Hurd S, Anzueto A, et al. Global strategy for the diagnosis, management, and prevention of chronic obstructive pulmonary disease: GOLD executive summary. Am J Respir Crit Care Med. 2007;176(6): 532-555.

7. Buist AS, McBurnie MA, Vollmer WM, et al; BOLD Collaborative Research Group. International variation in the prevalence of COPD (the BOLD Study): a population-based prevalence study. Lancet. 2007; 370(9589):741-750.

8. Guerriero M, Caminati M, Viegi G, Senna G, Cesana G, Pomari C. COPD prevalence in a north-eastern Italian general population. Respir Med. 2015;109(8):1040-1047.

9. Kim V, Criner GJ. The chronic bronchitis phenotype in chronic obstructive pulmonary disease: features and implications. Curr Opin Pulm Med. 2015;21(2):133-141.

Dove Medical Press encourages responsible, free and frank academic debate. The content of the International Journal of Chronic Obstructive Pulmonary Disease 'letters to the editor' section does not necessarily represent the views of Dove Medical Press, its officers, agents, employees, related entities or the International Journal of Chronic Obstructive Pulmonary Disease editors. While all reasonable steps have been taken to confirm the content of each letter, Dove Medical Press accepts no liability in respect of the content of any letter, nor is it responsible for the content and accuracy of any letter to the editor.

\section{Publish your work in this journal}

The International Journal of COPD is an international, peer-reviewed journal of therapeutics and pharmacology focusing on concise rapid reporting of clinical studies and reviews in COPD. Special focus is given to the pathophysiological processes underlying the disease, intervention programs, patient focused education, and self management protocols.

\section{Dovepress}

This journal is indexed on PubMed Central, MedLine and CAS. The manuscript management system is completely online and includes a very quick and fair peer-review system, which is all easy to use. Visit $\mathrm{http}: / / \mathrm{www}$. dovepress.com/testimonials.php to read real quotes from published authors. 